\title{
INSTITUTIONAL AND MANAGEMENT ANALYSIS OF THE AUCTION FISH PLACE (AFP) FOR IMPROVING FISHERMEN'S WELFARE IN TEGALSARI AFP, TEGAL CITY, CENTRAL JAVA
}

\author{
Teuku Junaidi ${ }^{1}$, Irfina Fitri Mardani ${ }^{1}$, and Arif Mahdiana ${ }^{1}$ \\ ${ }^{1}$ Fisheries and Marine Science University of Jenderal Soedirman , Purwokerto, Central Java, \\ Indonesia
}

\begin{abstract}
Institutional and Management Analysis of The Auction Fish Place (AFP) for Improving Fishermen's Welfare in Tegalsari AFP, Tegal City, Central Java" research aimed to find out the institutional system of Auction Fish Place (AFP) and Evaluation Strategy of Auction Fish Place (AFP) Tegalsari based on its institutional function. This research uses survey method which done by observation and interview. The data used are primary data and secondary data which then analyzed descriptively by using SWOT analysis. The result showed that the institutional and management system in Tegalsari AFP has been running well, from the performance of AFP managers and the tender system that runs smoothly in accordance with applicable regulations. The optimal management strategy of Tegalsari AFP is by improving the existing operational system in AFP, one of them is clean water facility and access to capital for local fisherman.
\end{abstract}

\section{Introduction}

Tegal city has one Coastal Fisheries Port (CFC) and three Fish Landing Port (FLP) namely Tegalsari CFC, Tegalsari FLP, Pelabuhan FLP, and Muarareja FLP. Tegalsari FLP is the largest fish landing port. The annual data showed that fish landed at Tegalsari FLP is more than other FLP in Tegal.

Auction Fish Place (AFP) is a public facility build for giving service to the people. AFP's performance is important to be measured for appropriate usage of the facility. AFP's performance can be measured from it is efficiency in auction and facility maintenance. The measurement of AFP performance is also important know customer satisfaction, the customer satisfaction usually keep the AFP active in auction and port economic development 
Auction Fish Place is a formal institution in fisheries sector. Fisherman use this facility to sell their catch. The problem whether AFP is already functioned optimally. AFP rules and system need to be fair for each consumers. Fair AFP will give profit to each of consumers, but if AFP only gives profit to specific consumers, it will lead to fishermen economical downfall [2].

The AFP is built for benefit of fishermen and fisheries cooperation, AFP's aim is to make fishermen prosper and succeed [3] Prosperity is lifestyle and social livelihood, material and spiritual need of safety, decency, and tranquility that give people the ability to fulfill their daily necessity for themselves or community [4]. The sea is rich of resources and having great economic potential that can be used to make fishermen prosper [5]. AFP need to be managed to be optimally functioned as economic development instrument for the fishermen in the vicinity.

Poverty is a state of inability to be able to meet basic needs such as food, clothing, shelter, education, and health. Poverty can be caused by the scarcity of the fulfillment tool basic needs, or difficult access to education and employment. Poverty is a global problem. Some people understand this term subjectively and comparative, while others see it in terms of moral and evaluative, and which others understand it from an established scientific standpoint [6].

SWOT application is how power is able to take profit from the opportunities available, how to overcoming weaknesses that prevent the advantage of opportunities that exists, then how can power be face the existing threat, and the last is how to cope weaknesses that can make the threats real or creating a new threat. SWOT is used to assess strengths and weaknesses from company's resources and opportunities and external challenges faced [7]. Aim and strategies are established with the intent of harnessing internal strength and coping weakness [8].

The aim of this research is to study the institution system and management of AFP Tegalsari to be optimally functioned. The research data will be a source of information to develop and managing AFP, then the fishermen prosperity in Tegal will increased.

\section{Material and Method}

The Material is Auction Fish Place (AFP) Tegalsari, Tegal. Data sampling using survey method. The first method is Institutional survey for secondary data. The second method is direct sampling at AFP.

Purposive Sampling was used in the research, the AFP sample target are AFP chairman, auctioneer, purchase casher, receive casher, secretary, treasurer, head of business unit, head of security. System Randomized Sampling was used to $10 \%$ of total fishermen, and $10 \%$ of total fish collectors. The sampling was done in December 2016.

\subsection{Data Analysis}

SWOT analysis method is used in the research. The method is used to observe working procedure, institution, and system in AFP Tegalsari. SWOT is used to know AFP Strength, Weakness, Opportunity, and Threat.

\section{Result and Discussion}

\subsubsection{Institutional System of AFP Tegalsari}

Table1. Managerial access to increase AFP performance to increase fishermen prosperity $(n=21)$ 
No.

1.

2.

Total
Description

AFP managerial does make

fishermen prosper.

AFP managerial does not

make fishermen prosper.

\section{Percentage}

$85.71 \%$

$14.29 \%$

$100 \%$

From the table, $85.71 \%$ of respondent stated that AFP managerial does make fishermen prosper. The result showed that AFP Tegalsari institution function is optimally working.

Table 2. Managerial access to balance the fish price in AFP $(n=21)$

No.

1.

2.

Total
Description

AFP managerial does balance the fish price

AFP managerial does not balance the fish price
Percentage

$76.19 \%$

$23.81 \%$

$100 \%$

From the table, $76.19 \%$ of respondent stated that AFP managerial does balance the fish price in AFP. The result showed that AFP Tegalsari institution function is optimally working.

Table 3. Managerial access to increase AFP performance to increase Locally-generated revenue

No.

1.

2.

Total

\section{Description}

AFP managerial does increase Locally-generated revenue
Percentage $95.23 \%$

$4.77 \%$ increase Locally-generated revenue

From the table, $95.23 \%$ of respondent stated that AFP managerial does increase Locally-generated revenue. The result showed that AFP Tegalsari institution function is optimally working.

Table 4. Managerial access to increase AFP performance to do social activity $(n=21)$

No.

1.

2.

Total
Description

Decision taken was based on family decision

Decision taken was not based on family decision
Percentage

$14.29 \%$

$85.71 \%$

$100 \%$

From the table, $85.71 \%$ of respondent stated that AFP managerial taken decision not based on family decision. The result showed that AFP can take a decision for every social activity followed.

Table 5. Managerial access to do lobbying

No. 
1.

2.
Managerial does lobbying to
$71.43 \%$
stakeholder (Government,
Ministry of Fisheries and
Marine, Local Government)
for solve the problem in AFP
Managerial does not
lobbying to stakeholder
(Government, Ministry of
Fisheries and Marine, Local
Government) for solve the
problem in AFP

\section{Total}

From the table, $71.43 \%$ of respondent stated that AFP managerial does lobbying to solve the AFP problem.

\subsubsection{Managerial Strategy of AFP Tegalsari}

Managerial strategy of AFP Tegalsari can be observed from internal factor (strength and weakness) and external factor (threat and opportunity)

a. Internal Factor of AFP managerial strategy can be a power for AFP Tegalsari to become a power to overcome a weakness and upcoming event.

Table 6. IFAS (Internal Factor Analysis Summary) matrix AFP Tegalsari managerial strategy to determine maximum value

\begin{tabular}{|c|c|c|c|c|c|c|}
\hline \multirow[t]{2}{*}{ No. } & \multirow[t]{2}{*}{ Internal Factors } & \multicolumn{2}{|c|}{ Score } & \multirow[t]{2}{*}{ Weight } & \multicolumn{2}{|c|}{ Value } \\
\hline & & Min & Max & & Min & Max \\
\hline 1 & Good Auction System & 1 & 4 & 10.7 & 10.7 & 42.8 \\
\hline 2 & $\begin{array}{l}\text { Good AFP Service } \\
\text { Performance }\end{array}$ & 1 & 4 & 10.7 & 10.7 & 42.8 \\
\hline 3 & Good AFP Security & 1 & 4 & 10.7 & 10.7 & 42.8 \\
\hline 4 & $\begin{array}{l}\text { Good Interaction Between } \\
\text { employers and customers }\end{array}$ & 1 & 4 & 10.7 & 10.7 & 42.8 \\
\hline 5 & $\begin{array}{l}\text { Total Fishermen and } \\
\text { Fisheries Community }\end{array}$ & 1 & 4 & 12.5 & 12.5 & 50 \\
\hline 6 & $\begin{array}{l}\text { AFP Geographical } \\
\text { Condition }\end{array}$ & 1 & 4 & 15 & 15 & 60 \\
\hline 7 & Less Clean Water Facility & 1 & 4 & 7.1 & 7.1 & 28.4 \\
\hline 8 & AFP Sanitation & 1 & 4 & 7.1 & 7.1 & 28.4 \\
\hline 9 & $\begin{array}{l}\text { Less Capital Access for } \\
\text { small fishermen }\end{array}$ & 1 & 4 & 7.1 & 7.1 & 28.4 \\
\hline 10 & KPLI Payment Overdue & 1 & 4 & 8.4 & 8.4 & 33.6 \\
\hline Total & & & & 100 & 100 & 400 \\
\hline
\end{tabular}

Data and information of strength and weakness of AFP arranged in IFAS matrix and analyzed for AFP Tegalsari institutional system and managerial. The value of internal factor (score $\mathrm{x}$ weight), maximum value was obtained. Internal factor criteria:

Very Good: $>80 \%$ ( $>320)$ Maximum value; strength of AFP Tegalsari is very good and dominant

Good: $70-80 \%$ (320-280) Maximum value; strength of AFP Tegalsari is good

Above Average: $60-70 \%$ (280-240) maximum value; strength of AFP Tegalsari is above average

Average: $50-60 \%$ (240-200) maximum value; weakness of AFP Tegalsari is average 
Bad: $<50 \%(<200)$ maximum value; weakness of AFP Tegalsari is dominant

From the IFAS matrix we can determine AFP Tegalsari internal condition. This matrix draw qualitative value of strength and weakness of AFP Tegalsari.

Table 7. IFAS matrix of AFP Tegalsari managerial strategy

\begin{tabular}{|c|c|c|c|c|}
\hline No. & $\begin{array}{l}\text { Internal Factors } \\
\text { (Strength) }\end{array}$ & Score & Weight & Value \\
\hline 1. & $\begin{array}{l}\text { Good auction operational } \\
\text { system }\end{array}$ & 4 & 10.7 & 42.8 \\
\hline 2. & $\begin{array}{l}\text { Good AFP service } \\
\text { performance }\end{array}$ & 4 & 10.7 & 42.8 \\
\hline 3. & Good AFP security & 4 & 10.7 & 42.8 \\
\hline 4. & $\begin{array}{l}\text { Good Interaction } \\
\text { Between employers and } \\
\text { customers }\end{array}$ & 3 & 10.7 & 32.1 \\
\hline 5. & $\begin{array}{l}\text { Total Fishermen and } \\
\text { Fisheries Community }\end{array}$ & 3 & 12.5 & 37.5 \\
\hline 6. & $\begin{array}{l}\text { Total Fishermen and } \\
\text { Fisheries Community }\end{array}$ & 3 & 15 & 45 \\
\hline \multicolumn{2}{|c|}{ (Sub-Total) } & & $\mathbf{7 0 . 3}$ & 243 \\
\hline No. & $\begin{array}{l}\text { Internal Factors } \\
\text { (Weakness) }\end{array}$ & Score & Weight & value \\
\hline 1. & $\begin{array}{l}\text { Less Clean Water } \\
\text { Facility }\end{array}$ & 1 & 7.1 & 7.1 \\
\hline 2. & AFP Sanitation & 1 & 7.1 & 7.1 \\
\hline 3. & $\begin{array}{l}\text { Less Capital Access for } \\
\text { small fishermen }\end{array}$ & 2 & 7.1 & 14.2 \\
\hline 4. & KPLI Payment Overdue & 2 & 8.4 & 16.8 \\
\hline \multicolumn{2}{|c|}{ (Sub-total) } & & 29.7 & 45.2 \\
\hline \multicolumn{2}{|c|}{ Total } & & 100 & 288.2 \\
\hline
\end{tabular}

Based on IFAS (table 7), there are six strength factors and four weakness factor in AFP Tegalsari managerial system. AFP location, and total fishermen and fisheries community got highest weight in the strength factors. The weakness of AFP Tegalsari were overdue KPLI payment. Internal aspect analysis resulted in value of 288.2 in AFP Tegalsari. The result showed that AFP Tegalsari internal factor in good condition.

b. External factor consist of opportunity that need to be utilized and threat that need to be overcame in AFP Tegalsari managerial system.

Table 8. External Factor Analysis Summary (EFAS) of AFP Tegalsari strategy to determine maximum value

\begin{tabular}{|c|c|c|c|c|c|c|}
\hline \multirow[t]{2}{*}{ No. } & \multirow[t]{2}{*}{ External Factor } & \multicolumn{2}{|c|}{ Score } & \multirow{2}{*}{$\begin{array}{c}\text { Weigh } \\
t\end{array}$} & \multicolumn{2}{|c|}{ Value } \\
\hline & & Min & Max & & Min & Max \\
\hline 1 & Good Marketing & 1 & 4 & 9.9 & 9,9 & 39,6 \\
\hline 2 & $\begin{array}{l}\text { Tegal geographical } \\
\text { location }\end{array}$ & 1 & 4 & 11.4 & 11.4 & 45.6 \\
\hline 3 & $\begin{array}{l}\text { High potential in } \\
\text { Fisheries }\end{array}$ & 1 & 4 & 9.9 & 9.9 & 39.6 \\
\hline 4 & $\begin{array}{l}\text { AFP income from } \\
\text { Highest PAD }\end{array}$ & 1 & 4 & 8.2 & 8.2 & 32.8 \\
\hline
\end{tabular}




\begin{tabular}{|c|c|c|c|c|c|c|}
\hline 5 & Fish price stability & 1 & 4 & 12 & 12 & 48 \\
\hline 6 & $\begin{array}{l}\text { Water pollution affect } \\
\text { fish quality }\end{array}$ & 1 & 4 & 10.4 & 10.4 & 41.6 \\
\hline 7 & $\begin{array}{l}\text { Bad weather and } \\
\text { climate, global } \\
\text { warming }\end{array}$ & 1 & 4 & 13.1 & 13.1 & 52.4 \\
\hline 8 & Wholesaler dependency & 1 & 4 & 7.1 & 7.1 & 28.4 \\
\hline 9 & $\begin{array}{l}\text { Low on education and } \\
\text { experience }\end{array}$ & 1 & 4 & 7.6 & 7.6 & 30.4 \\
\hline 10 & $\begin{array}{l}\text { Dominant in small } \\
\text { fishermen }\end{array}$ & 1 & 4 & 10.4 & 10.4 & 41.6 \\
\hline Tot: & & & & 100 & 100 & 400 \\
\hline
\end{tabular}

Data and information about opportunity and threat of AFP Tegalsari institutional and managerial system analyzed using EFAS. The value (score $\mathrm{x}$ weight) for external factors, the criteria were:

Very Good: $>80 \%(>320)$ maximum value; AFP Tegalsari respond to opportunity very well. Good: $70-80 \%$ (320-280) maximum value; AFP Tegalsari respond to opportunity well. Above Average: $60-70 \%$ (280-240) maximum value; AFP Tegalsari respond to opportunity is above average

Average: 50-60\% (240-200) maximum value; AFP Tegalsari not responding to opportunity well.

Bad: $<50 \%(<200)$ maximum value; AFP Tegalsari respond to opportunity is bad.

EFAS matrix used to determine external factor condition in AFP Tegalsari. EFAS matrix draw qualitative value from opportunity and threat in AFP Tegalsari managerial system.

No.

Table 9. EFAS matrix of AFP Tegalsari managerial strategy.

External Factor

Score Weigh Value

(Opportunity)

1. Good Marketing

2. Tegal geographical location

3. High potential in Fisheries

4. AFP income from Highest PAD

5. Fish price stability

(Subtotal)

(Threath)

$\begin{array}{llccc}\text { 1. } & \text { Water pollution affect fish quality } & 2 & 10.4 & 20.8 \\ \text { 2. } & \text { Bad weather and climate, global } & 1 & 13.1 & 13.1 \\ & \text { warming } & & & \\ \text { 3. } & \text { Wholesaler dependency } & 2 & 7.1 & 14.2 \\ \text { 4. } & \text { Low on education and experience } & 2 & 7.6 & 15.2 \\ 5 . & \text { Dominant in small fishermen } & 2 & 10.4 & 20.8 \\ \text { otal) } & & & \mathbf{4 8 . 6} & \mathbf{8 4 . 1} \\ & & \mathbf{1 0 0} & \mathbf{2 6 7 . 8}\end{array}$

(Subtotal)

Total

Based on table 9, there are five opportunity and five threat analyzed in AFP Tegalsari external factor. Stable fish price in AFP Tegalsari was the highest opportunity, and the highest threat in AFP Tegalsari was bad weather and climate because of global warming. 
External factor analyzed in AFP Tegalsari managerial system resulted in 267.8 in value. This value showed that AFP Tegalsari external factor in good condition, it means AFP Tegalsari can respond to opportunity well.

SWOT matrix analyzed to determine AFP Tegalsari Managerial strategy. SWOT matrix showed a combination between internal and external factors:

Table 10. SWOT matrix of AFP Tegalsari Managerial

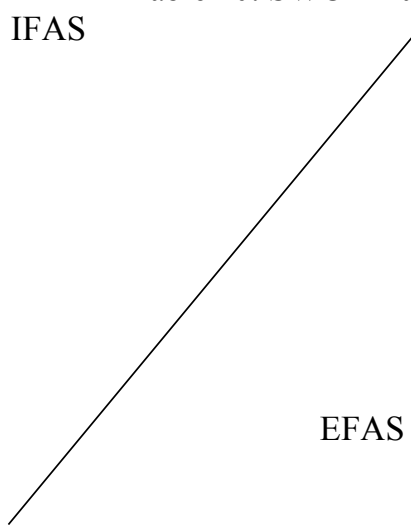

Opportunity

1. Good Marketing

2. Tegal geographical location

3. High potential in

Fisheries

4. AFP income from

Highest PAD

5. Fish price stability

\section{Threat}

1. Water pollution affect

fish quality

2. Bad weather and climate, global warming

3. Wholesaler dependency

4. Low on education and experience

5. Dominant in small

fishermen
Strength

1. Good auction operational system

2. Good AFP service performance

3. Good AFP security

4. Good Interaction

Between employers and customers

5. Total Fishermen and

Fisheries Community

6. Total Fishermen and

Fisheries Community

SO Strategy:

1. Increased market share and distribution network of fishery products

2. Increased fishery activities in terms of quantity and capacity of fishery products

\section{ST Strategy:}

1. Maintaining TPI's operational system and improving TPI

infrastructure for market development so that TPI is not only dominated by small fishermen as well as increasing capital in TPI Tegalsari
Weakness

1. Less Clean Water

Facility

2. AFP Sanitation

3. Less Capital Access for small fishermen

4. KPLI Payment Overdue

\section{WO Strategy :}

1. Water supply to support

TPI operations

2. Improve TPI hygiene

3. Memberikan akses kepada nelayan untuk mendapatkan modal usaha 4. Conduct a policy for timely payment of KPLI

\section{WT Strategy:}

1. Improved cleanliness and facilities of TPI to increase comfort in TPI so as to attract buyers

2. Providing capital so that fishermen can still operate

Once the internal and external factors are combined, it will be variously known strategies that suit the environmental conditions of both internal and external environments management of AFP Tegalsari. The strategy has four possibilities:

1) SO Strategy

SO 1: Increased market share and distribution network of fishery products

SO 2: Increased fishery activities in terms of quantity and capacity of fishery products

2) Strategy $S T$

Keeping AFP's operational system in good condition and improving the infrastructure facilities of AFP agar the development of the market so that AFP is not only dominated by small fishermen as well increased capital in AFP Tegalsari 
3) WO Strategy

WO 1: Provision of clean water to support AFP operations

WO 2: Improve AFP hygiene

WO 3: Provide access to fishermen to obtain business capital

WO 4: Conduct a policy for timely payment of KPLI

4) WT Strategy

WT1: Improved cleanliness and facilities AFP to improve comfort at AFP thus attracting buyers

WT 2: Provide capital so that fishermen can still operate

\section{Conclusion}

The institutional and management system in AFP Tegalsari has been operating functionally, observed from the performance of AFP managers, as well as auction system that runs smoothly accordingly with applicable regulations. AFP Tegalsari management strategy is optimal by improving the existing operational systems in the AFP is one of them is a facility clean water and access to capital for local fishermen, so the welfare of fishermen in TPI Tegalsari region can be improved

\section{References}

1. Resti, F.D. Pengukuran Kinerja Pengelolaan Tempat Pelelangan Ikan di PPI Muara Angke, Skripsi (Institut Pertanian Bogor, Bogor, 2012)

2. Silalahi, D.G, Aktivitas Kelembagaan Tempat Pelelangan Ikan Sebagai Kelembagaan Ekonomi Masyarakat Nelayan (Studi Kelembagaan Tempat Pelelangan Ikan, Kelurahan Pelabuhanratu, Kecamatan Pelabuhanratu, Kabupaten Sukabumi, Propinsi Jawa Barat), Skripsi, (Institut Pertanian Bogor, Bogor, 2006)

3. Pramitasari, S.D, Analisis Efesiensi TPI (Tempat Pelelangan Ikan Kelas 1, 2 dan 3 di Jawa Tengah dan Pengembangannya Untuk Peningkatan Kesejahteraan Nelayan, Tesis, (Universitas Diponegoro, Semarang, 2005)

4. Rambe, A, Alokasi Pengeluaran Rumah Tangga dan Tingkat Kesejahteraan (Kasus di Kecamatan Medan, Kota Sumatra Utara, Tesis, (Institut Pertanian Bogor, Bogor, 2004)

5. Imron, M, Kemiskinan Dalam Masyarakat Nelayan, Jurnal Masyarakat dan Budaya. Vol 5, 1: 63-82, (2003)

6. Retnowati, E, Nelayan Indonesia Dalam Pusaran Kemiskinan Struktural (Perspektif Sosial, Ekonomi, dan Hukum), Jurnal Perspektif, Vol 16, 3: 149-159, (2011)

7. Jogiyanto, Sistem Informasi Strategik Untuk Keunggulan Kompetitif, (Andi Offset, Yogyakarta, 2005)

8. David, F.R, Manajemen Strategis (Edisi Sepuluh), (Salemba Empat, Jakarta, 2006) 